\title{
MODEL PEMBELAJARAN MANDIRI SEBAGAI UPAYA PENINGKATAN USAHA PETANI TAMBAK DI DESA TATELU SULAWESI UTARA
}

\author{
Mozes M. Wullur \\ Jurusan Pendidikan Luar, Sekolah Fakultas Ilmu Pendidikan, Universitas Negeri Manado \\ Jalan Tondano, Sulawesi Utara 95618 \\ E-mail: wullur.mozes@yahoo.com
}

\begin{abstract}
ABSTRAK
Penelitian ini bertujuan mendeskripsikan model pembelajaran mandiri bagi petani tambak terkait dengan motivasi, proses, dan hasil belajar mandiri. Penelitian ini menggunakan penelitian kualitatif. Pengumpulan data melalui observasi, wawancara, dan dokumentasi. Proses analisis data bersamaan dengan pengumpulan data. Hasil penelitian disimpulkan bahwa: Motivasi belajar mandiri petani meliputi motivasi internal dan eksternal; proses belajar mandiri petani meliputi kesiapan belajar, interaksi belajar, dan implementasi hasil interaksi belajar mandiri; sedangkan hasil belajar mandiri terjadi peningkatan pengetahuan, sikap dan keterampilan, dan terjadi peningkatan pendapatan keluarga. Saran bagi petani terus meningkatan pengetahuan dan keterampilan yang dimiliki, ikhlas menjadi nara sumber,dan terus menabung, dengan dukungan semua stakeholder yang terkait.
\end{abstract}

Kata kunci: model pembelajaran mandiri, petani tambak, budidaya,ikan mas

\section{INDEPENDENT LEARNING MODEL AS AN EFFORT OF THE IMPROVEMENT OF FARMERS FISH POND IN TATELU VILLAGE NORTH SULAWESI}

\begin{abstract}
This research aimed to describe a model of independent learning for farmers of fishpond concerning to their motivation., proces and independent learning result. This research used a qualitative research. Data collection was through observation, interviews and documentation. Data analysis process was together with data collection. The result of this research was concluded that independent learning motivation of farmers included internal motivation and external, independent learning proces of farmers included learning readiness, learning interaction, and implementation of independent learning interaction result ; where as the independent learning result incurred an improvement in knowledge, behavior and skills and incurred an increas to the family's income. Suggestion to the farmers are to continue to increas the knowledge and skills by them, sincere becoming a resource person and keep on saving with the support of stakeholders associated.
\end{abstract}

Keywords : Independent learning model, fishpond farmers, gold fish cultivation 


\section{PENDAHULUAN}

Pembangunan masyarakat merupakan suatu proses perubahan secara sengaja untuk memenuhi kebutuhan-kebutuhan masyarakat. Dikatakan demikian karena perubahan kebutuhan masyarakat sejalan dengan perubahan peradaban yang dipengaruhi peningkatan perkembangan kemajuan ilmu pengetahuan, teknologi dan seni (IPTEKS) melalui transformasi pendidikan.

Pembangunan sebagai suatu proses menunjuk pada konsep bahwa pembangunan merupakan suatu rangkaian aktivitas masyarakat yang tidak akan pernah berakhir dimana aktivitas masyarakat terus bergerak maju atas kekuatan sendiri (Self sustaining process) untuk semua aspek kehidupan ke arah perubahan sosial. Perubahan sosial dimaksud menurut Macionis, dalam Piotr Sztompka, (2010:5) ialah "perubahan pola perilaku, hubungan sosial, lembaga dan struktur sosial pada waktu tertentu". Kondisi ini menunjukkan gejala bahwa masyarakat memiliki potensi sumber-sumber daya yang siap dioptimalkan baik oleh diri sendiri, sesama masyarakat maupun oleh pemerintah ke arah peningkatan kualitas kelayakan hidup.

Upaya untuk meningkatkan martabat dan mutu kehidupan masyarakat bertolak dari adanya kesadaran yang terinternalisasi bagi masyarakat untuk menemukan jati dirinya secara mandiri dalam kebersamaan guna mencari dan menemukan sumber dan media belajar pendidikan kecakapan hidup (life skill) melalui pendidikan mata pencaharian. Dalam konteks pendidikan luar sekolah upaya mencari dan menemukan sumber serta media belajar secara mandiri oleh masyarakat sebagai warga belajar pendidikan luar sekolah, masuk dalam wilayah pendidikan orang dewasa. Pandangan ini diperjelas oleh Bryson dalam Supriyanto, (2005:13) yang menyatakan bahwa pendidikan orang dewasa ialah: "semua aktivitas pendidikan yang dilakukan oleh orang dewasa dalam kehidupan sehari-hari yang hanya menggunakan sebagian waktu dan tenaganya untuk mendapatkan tambahan intelektual".

Untuk kelancaran dan keberhasilan kegiatan belajar mandiri bagi petani harus memilik prasayarat utama yaitu adanya kesiapan belajar mandiri. Kesiapan belajar mandiri dimaksud meliputi: (1). Kemampuan mengidentifikasi kebutuhan belajar, menetapkan tujuan belajar, (2). Kemampuan menetapkan tujuan belajar, (3). Menetapkan rencana kegiatan belajar, (4). Menentukan sumber dan media belajar, (5). Menentukan waktu belajar secara penuh, (6). Merefleksikan bahan pelajaran yang diperoleh, (7). Tekad memecehkan masalah yang dihadapi secara kreatif, (8). Mengadakan penilaian sendiri dan bersedia melakukan kerjasama dengan orang lain.

Pandangan tersebut, didukung oleh Syamsu Mappa, (1994:29) bahwa: "Warga belajar mencari informasi melalui bahan bacaan di perpustakaan, mempelajari catatan, mengamati hasil percobaan dalam laboratorium, mengadakan observasi..." mengindikasikan adanya kesiapan belajar oleh orang dewasa.

Konsep dan implementasi aktivitas belajar mandiri bagi orang dewasa dalam pendidikan luar sekolah oleh Stephen Brookfield (1983) disebut "Independence Learning" yaitu belajar 
mandiri. Keunggulan belajar mandiri bahwa orang dewasa belajar didominasi oleh motivasi internal sebagai warga belajar untuk memanfaatkan sumber dan media belajar dalam proses interaksi belajar. Dikatakan demikian karena belajar bagi orang dewasa mempunyai keunikan tersendiri. Keunikan dimaksud bahwa orang dewasa dalam melakukan kegiatan belajar mempunyai sejumlah pengalaman, kemampuan dan motivasi. Itulah sebabnya Rogers, (1983) mengemukakan cara belajar ini dengan istilah "Student centered or learning centered" yaitu kegiatan belajar yang terpusat pada warga belajar. Hal ini dilandasi pemahaman bahwa belajar bagi orang dewasa berkaitan erat dengan pekerjaan untuk memenuhi kebutuhan hidup mereka, sehingga belajar mandiri ini dilakukan dalam pekerjaannya (learning by doing) yaitu belajar sambil bekerja.

Terkait dengan konsep belajar mandiri bagi orang dewasa, Stephen Brookfield (1983:x) mengemukakan konsep analisis belajar mandiri bagi orang dewasa yaitu :"(1). Independent learning and correspondence study; (2) indepencence in learning; (3) sefl-teaching; (4) self-directed learning; (5) autonomous learning; (6) independence learning as the aim of education; and (7) voluntary learning".

Berdasarkan analisis tersebut, belajar mandiri bagi orang dewasa dapat berlangsung dengan cara belajar sendiri dan belajar melalui korespondensi yaitu dengan sistem paket atau modul. Adanya kemerdekaan atau kebebasan bagi orang dewasa dalam proses kegiatan belajar, orang dewasa mengajar dirinya sendiri melalui pengalaman belajar baik yang berhasil maupun kegagalan yang pernah dialami. Dalam melakukan kegiatan belajar, orang dewasa mempunyai kemampuan untuk mengarahkan diri, serta lebih bersifat otonom dalam pengambilan keputusan belajar, dan orang dewasa mempunyai kehendak sendiri untuk menetapkan tujuan belajar yang hendak dicapai, serta adanya kesukarelaan baginya untuk melakukan kegiatan belajar.

Bagi masyarakat petani di daerah pedesaan, konsep belajar ini sering dijumpai dalam pelaksanaan tugas pekerjaan setiap hari. Dengan demikian mereka dapat dengan mudah melakukan kegiatan belajar berkenaan dengan kebutuhan belajar yang diinginkan, dengan cara melakukan kegiatan interaksi belajar dengan sumber dan media belajar yang dapat terjangkau. Hal ini sangat didukung oleh kemampuan orang dewasa untuk melakukan perencanaan dalam aktivitas pendidikan luar sekolah.

Perencanaan ini mengacu pada konsep Shrode \& Voice dalam (M.Wullur, 2010: 26) yang mengemukakan bahwa: The planning process is the vechile for transforming perceptions about environmental conditions in to meaningful and magageable operating plans" yang artinya, proses perencanaan sebagai alat mentransformasikan persepsi-persepsi mengenai kondisi-kondisi lingkungan ke dalam rencana yang berarti dan dapat dilaksanakan secara teratur. Perencanaan belajar mandiri bagi petani dikalangan masyarakat pedesaan, telah berlangsung dan merupakan potensi dasar bagi pemerintah dan tokoh masyarakat untuk menggerakan aktivitas pembangunan masyarakat desa, dengan menggunakan pendekatan analisis sistem yang harus dipahami dan dilakukan oleh orang dewasa dalam melaksanakan kegiatan 
belajar mandiri. Analisis sistem tersebut memiliki komponen-komponen sebagaimana pandangan Turang dalam M. Wullur (2011:16) yang meliputi:“ (1) komponen masukan, (2) komponen proses, (3) komponen keluaran, dan (4) komponen dampak". Bagi petani sebagai warga belajar dalam melaksanakan aktivitas belajar mandiri, dipandang perlu dan amat penting menganalisis komponen-komponen dalam satu kesatuan sistem tersebut sebelum dan selama melaksanakan kegiatan belajar mandiri untuk mengelola usaha budidaya ikan mas.

Desa Tatelu Kecamatan Dimembe Kabupaten Minahasa merupakan salah satu desa yang menjadi sentra pengembangan usaha budidaya ikan mas propinsi Sulawesi Utara. Ketertarikan masyarakat untuk menekuni usaha ini disebabkan oleh motivasi internal dan motivasi eksternal. Motivasi internal, meliputi pengetahuan awal tentang pengelolaan budidaya ikan mas oleh petani, adanya wawasan berpikir masa depan, dan orientasi nilai budaya tentang pengelolaan budidaya ikan mas. Sedangkan motivasi eksternal meliputi kondisi ekonomi petani pada umumnya kelompok masyarakat ekonomi lemah, kondisi geografis, tersedianya sumber belajar dan media belajar yang memungknkan bagi petani untuk melakukan interaksi belajar secara mandiri. Faktor pendukung lainnya bagi petani untuk melakukan usaha budidaya ikan mas meliputi: (a). Adanya potensi sumber air bersih yang melimpah dan tidak tergantung dari musim penghujan, (b). Pergantian musim kemarau dan musim penghujan yang teratur setiap tahun berjalan, (c) tanahnya terkategori subur yang ditandai dengan bertumbuhnya berbagai jenis tumbuhan, (d).
Jarak lokasi pembudidayaan ikan mas dengan pusat pemasaran kota Manado sekitar $24 \mathrm{~km}$. Selain dari faktor geografis, faktor pemasaran hasil produksi ikan mas juga mendukung petani untuk meningkatkan dan mengembangkan usahanya karena komsumsi daging ikan mas juga telah menjadi menu khas daerah Sulawesi Utara sebagai menu harian, menu pesta maupun menu duka, dan menu tamu wisatawan baik domestik maupun manca negara.

Dalam rangka pengembangan usaha budidaya ikan mas, pemerintah telah menempatkan petugas Penyuluh Pertanian Lapangan (PPL), dan ditingkatkannya status Balai Benih Ikan (BBI) di Kecamatan Dimembe menjadi Loka Budidaya Ikan Air Tawar Propinsi Sulawesi Utara dengan berbagai program proyek percontohan (Demplot), telah mendorong masyarakat yang tidak terjangkau dengan lalayan penyuluhan oleh petuga PPL untuk menekuni usaha budidaya ikan mas. Masyarakat petani ini bersedia dan mampu melakukan usaha-usaha untuk mencari dan menemukan sumber dan media belajar untuk belajar budidaya ikan mas dengan cara belajar mandiri. Dengan demikian, penelitian ini mengkaji tentang bagaimana wujud model belajar mandiri petani dalam meningkatkan usaha budidaya ikan mas berdasarkan faktor-faktor kesiapan belajar petani yang tidak memperoleh penyuluhan langsung oleh Petugas Penyuluh Lapangan yang diprogramkan oleh Dinas Perikanan Propinsi Sulawesi Utara. Penelitian ini mengambil fokus tentang:

1. Bagaimana motivasi belajar mandiri petani dalam meningkatkan usaha budidaya ikan mas? 
2. Bagaimana proses belajar mandiri petani dalam meningkatkan usaha budidaya ikan mas?

3. Bagaimana hasil belajar mandiri petani dalam meningkatkan usaha budidaya ikan mas dari aspek:

1) Peningkatan pengetahuan, sikap dan keterampilan petani?

2) Peningkatan pendapatan keluarga petani?

3) Pengembangan usaha budidaya ikan mas oleh petani.

Penelitian ini diharapkan dapat bermanfaat:

Pertama, dapat dijadikan kajian konseptual teoretik tentang konsep belajar mandiri bagi orang dewasa (andragogy) sebagai cakupan wilayah kajian pendidikan luar sekolah.

Kedua, sebagai bahan masukan bagi perencana dan pelaksana program pendidikan luar sekolah khususnyapihak Dinas Perikanan dan Kelautan Propinsi Sulawesi Utara dalam rangka optimalisasi program Loka Budidaya Ikan Tawar melalui peningkatan mutu pelayanan penyuluhan oleh petugas PPL yang didukung oleh pemerintah kabupaten, kecamatan serta pemerintah desa setempat.

\section{METODE PENELITIAN}

Penelitian ini menggunakan pendekatan penelitian Kualitatif (qualitative approach), yang merujuk pada pandangan Bogdan dan Biklen, 1982:31), yang antara lain mengemukakan bahwa: " pendekatan kualitatif berusaha untuk memahami dan menafsirkan makna tentang sesuatu peristiwa interaksi perilaku manusia dalam situasi tertentu menurut perspektif peneliti sendiri”. Penelitian ini mengambil lokasi di desa
Tatelu Kecamatan Dimembe Kabupaten Minahasa Utara, pada 2 Juli sampai dengan 30 Nopember 2013. Informan penelitian ini dibedakan menjadi dua yakni informan utama yaitu 4 orang petani yang melakukan aktivitas belajar mandiri dalam usaha budidaya ikan mas, petugas PPL perikanan, dan petugas loka budidaya ikan air tawar Tatelu, dan informan pendukung ialah para pedagang pengecer ikan mas, Tokoh masyarakat, dan Pemerintah desa Tatelu.

Data yang dibutuhkan diperoleh melalui observasi dan wawancara mendalam yang dirancang dalam bentuk pedoman wawancara dan pedoman observasi yang mengacu pada fokus permasalahan, serta data dokumentasi. Dalam proses pengumpulan data dibarengi dengan proses analisis data. Setiap data yang berhasil dikumpulkan dalam satu tahapan dilakukan analisis dengan mengacu pada pola Bogdan dan Biklen (1992:189) yaitu menelaah data, memilahnya ke dalam satuan-satuan atau memberi kode-kode tertentu, membuat sintesa, berusaha mencari pola, berusaha menemukan sesuatu yang penting (besar" dan "unik" sehingga menarik dan perlu dipelajari secara ilmiah, dan akhirnya mengambil keputusan dan selanjutnya ditulis secara sistimatik pada laporan penelitian.

Analisis data dalam penelitian ini dilakukan dengan cara induktif abstraktif. Untuk keabsahan data, terdapat beberapa kriteria yang ditetapkan dalam penelitian ini, yakni : kredibilitas (untuk validitas internal), transferabilitas (untuk validitas eksternal, dependabilitas (untukreliabilitas), dan konfirmabilitas (untuk objektivitas). 


\section{HASIL DAN PEMBAHASAN}

Berdasarkan hasil analisis data ditarik kesimpulan sebagai berikut:

1. Keempat informan memiliki motivasi belajar mandiri untuk memenuhi kebutuhan dasar yaitu: sandang, pangan, kesehatan, dan pendidikan yang menjadi motivasi awal.

2. Kadar motivasi masing-masing petani berbeda sehingga memberi dampak terhadap wujud motivasi belajar mandiri petani yang berbeda pula. Informan BK mempelajari dan menekuni pengelolaan budidaya ikan mas mulai dari benih larva, sampai menjadi ikan mas komsumsi. Informan ML mempelajari dan menekuni benih ikan mas ukuran $3-5 \mathrm{~cm}$ sampai menjadi ukuran $12-15 \mathrm{~cm}$. Sedangkan informan Gg mempelajari dan menekuni benih ukuran larva menjadi ukuran $6-8$ $\mathrm{cm}$. Sedangkan informan FM mempelajari dan menekuni benih ukuran $12 \quad-15 \mathrm{~cm}$ hingga menjadi ikan mas komsumsi.

3. Proses belajar mandiri berlangsung dalam bentuk interaksi belajar petani dengan petugas Loka Budidaya Ikan Air Tawar, petugas PPL, sesama petani dan membaca buku pinter tentang pengelolaan budidaya ikan mas. Radio dan Televisi hanya memberikan motivasi belajar karena materi belajar yang ditayangkan tidak sulit diikuti oleh petani karena jadwal penayangan dan pemberitaan hanya diikuti secara tidak sengaja oleh petani sehingga petani tidak siap untuk belajar.

4. Dalam proses interaksi belajar, berlangsung dengan cara tanya jawab, diskusi, melihat contoh, mempertimbangkan, menetapkan, melaksanakan, dan mengevaluasi.

5. Hasil belajar mandiri bagi petani pada umumnya memperoleh peningkatan pengetahuan, keterampilan, serta adanya perubahan sikap, terpenuhinya kebutuhan sandang, pangan, papan, kesehatan, dan pendidikan oleh petani dan keluarganya.

6. Hasil belajar ini memberi dampak positif bagi petani yaitu munculnya kebutuhan belajar baru baginya untuk meningkatkan usaha budidaya ikan mas. Untuk memenuhi kebutuhan belajar tersebut, ia melakukan renovasi terhadap proses belajar sebelumnya berdasarkan pertimbangan evaluasi yang dilakukan.

Berdasarkan temuan-temuan hasil penelitian dioeroleh temuan model belajar mandiri petani bahwa masing-masing petani memiliki model belajar mandiri yang berbeda sesuai dengan kebutuhan belajar, tujuan belajar, serta situasi dan kondisi petani yang turut mempengaruhi perbedaan belajar bagi masing-masing petani. Hal ini memberi kontribusi terhadap hasil belajar petani satu dengan petani lainnya dalam meningkatkan usaha budidaya ikan mas.

1. Motivasi belajar mandiri petani dalam meningkatkan usaha budidaya ikan mas

\section{a. Motivasi Internal}

i. Pengetahuan petani tentang pengelolan budidaya ikan mas. Pada umumnya petani telah memiliki pengetahuan awal tentang pengelolaan budidaya ikan mas melalui orang tua. Pengetahuan tersebut diperoleh ketika orang tua memelihara ikan mas di sawah. Sambil membantu orang tua melakukan pekerjaan tersebut 
mereka memperhatikan, bertanya dan menganalisanya, kemudian melakukan sesuai petunjuk. Dalam hal tertentu, pengalaman yang diamatinya melalui petani tetangga, dijadikannya bahan pertimbangan buat orang tua. Dalam pendidikan luar sekolah, cara belajar petani untuk mengelola budidaya ikan mas ini berlangsung dalam bentuk

pendidikan magang. Konsep ini didukung oleh teori magang menurut Djudju Sudjana (2006:265), mengemukakan: "Magang sebagai cara memberi dan menerima informasi yang telah ada dalam kehidupan manusia telah berhasil menjembatani pemindahan pengalaman seseorang kepada orang yang belum memiliki pengalaman sehingga orang terakhir tersebut mampu berdiri sendiri".

ii. Orientasi masa depan

Bagi petani, motivasi yang berorientasi masa depan muncul setelah mempelajari gejala bahwa kebutuhan akan komsumsi ikan mas di kalangan masyarakat semakin meningkat. Dengan meningkatnya kebutuhan ini, membawa dampak terhadap upaya peningkatan produksi mulai dari benih ikan mas sampai pada produksi ikan mas komsumsi. Kenyataan ini memperkuat keyakinan petani bahwa usaha budidaya ikan mas mempunyai prospek yang layak di masa yang akan datang. Konsep belajar berwawasan masa depan ini masuk dalam wilayah kajian belajar inovatif. Proses belajar inovatif ini didukung oleh pandangan (James Botkin, et all, 1979:24) dikenal dengan konsep "innovativie learning” yang meliputi "antisipative learning and participatory learning" yaitu belajar antisipatif dan belajar partisipatif. Belajar antisipatif ini muncul setelah mempelajari berbagai karakteristik sebagai fenomena yang menggejala dan yang sedang terjadi sekarang untuk mengantisipasi situasi kehidupan dimasa yang akan datang. Dengan demikian belajar antisipatif berorientasi ke masa depan sehingga terjadi konsep belajar sedini mungkin untuk berbuat sesuatu sebagai bekal hari esok agar tidak terjadi "Shock learning" (belajar mendadak) karena ketidak siapan menghadapi kenyataan yang ada pada waktunya. Untuk mewujudkan konsep belajar antisipatif ini, mutlak dan harus ditindaklanjuti dengan belajar partisipatif. Belajar tidak mutlak "given" atau inisiatif pemberian dari sumber belajar, melainkan inisiatif dan partisipasi belajar oleh petani guna memperoleh pengetahuan dan keterampilan dalam mengelola usaha budidaya ikan mas dari sumber dan media belajar atau fasilitas belajar yang ada dan mungkin yang diadakan inilah yang menjadi pemicu implementasi konsep belajar mandiri dari petani.

iii. Orientasi nilai budaya petani terhadap pengelolaan usaha budidaya ikan mas. Pengelolaan usaha budidaya ikan mas pada hakikatnya sebuah karya pekerjaan yang diwariskan oleh leluhur. Hal ini didukung oleh Kluckhon (dalam Koentjaraningrat,1990:31), yang 
mengemukakan lima dimensi orientasi nilai budaya masyarakat yang berkaitan dengan masalah dasar dalam hidup manusia tentang hakikat hidup manusia (MH), Hakikat Karya (HK), persepsi manusia tentang waktu (MW), pandangan manusia terhadap alam (MA) dan hakikat hubungan manusia dengan sesama (MM). Dalam implementasi belajar mandiri dalam kebersamaan untuk usaha budidaya ikan mas dalam konteks budaya Minahasa dikenal dengan konsep "Mapalus" yaitu bekerja bersama atau gotong royong dalam mengelola lahan sawah sebagai kolam air tenang, merekayasa budaya yang menjadikan budidaya ikan mas sebagai obyek komsumsi keluarga dikembangkan menjadi usaha sebagai sumber mata pencaharian utama petani untuk meningkatkan kesejahteraan hidup.

\section{b. Motivasi Eksternal}

i. Kondisi ekonomi petani.

Keadaan kondisi ekonomi keluarga petani menjadi salah satu motivasi eksternal petani melakukan kegiatan belajar mandiri dalam usaha budidaya ikan mas. Hasil penelitian menunjukkan bahwa sumber pemenuhan kebutuhan petani bergantung pada hasil usaha budidaya ikan mas. Walau pun terdapat petani yang tidak memiliki lahan pengelolaan usaha budidaya ikan mas sebagai milik sendiri, namun mereka tetap berkerja bersama dengan pemilik lahan dengan sistem bagi hasil, atau dengan sistem sewa tahunan. Temuan ini didukung oleh pandangan (Djudju Sudjana, 1991:23) bahwa:

“... didalam kenyataan kehidupan di masyarakat, kegiatan untuk memenuhi kebutuhan dasar ini sering dihubungkan dengan upaya untuk mendapatkan uang. Manusia tertarik untuk memperoleh uang bukan karena bentuk dan jenis uang semata-mata melainkan karena nilai tukar yang dimilikinya. Nilai tukar inilah yang berfaedah untuk memenuhi kebutuhan dasar seperti untuk membeli makanan, pakaian, atau untuk memiliki rumah"

ii. Kondisi geografis lokasi budidaya ikan mas. Kondisi geografis usaha budidaya ikan mas bagi petani merupakan salah satu faktor eksternal. Hasil penelitian menunjukkan umumnya lokasi geografis sawah atau kolam air tenang dan kolam air deras petani berjarak sekitar 100 meter hingga 1.500 meter dari pemukiman dan dapat ditempuh melalui kendaraan roda dua. Di pihak lain kualitas sumber air tidak tercemar dengan limbah keluarga, maupun industri. Dari aspek pemasaran, umumnya saat panen ikan mas tidak jauh dengan kios-kios penampungan benih ikan mas dan ikan mas komsumsi. Pada kioskios tersebut telah tersedia oksigen untuk kantor-kantong oksigen yang berisikan benih maupun ikan mas komsumsi sampai kepada konsumen. Temuan ini diperkuat oleh Nursid Sumaatmadja (1990:35) bahwa" ... studi dan analisa geografi dalam merencanakan suatu kegiatan meliputi analisa gejala manusia dengan gejala alam, dan meliputi pula analisis 
penyebarannya - interelasinya-

interaksinya dalam ruang".

iii. Tersedianya sumber dan media belajar. Tersedianya sumber dan media beajar mandiri petani merupakan salah satu faktor eksternal yang ditemukan di lapangan. Sumber dan media belajar tersebut meliputi: (a) petugas penyuluh lapangan (PPL) loka budiaya ikan air tawar Tatelu, (b) petani yang telah mengikuti program penyuluhan dan pelatihan oleh Dinas Perikanan dan Kelautan, (c) petani lainnya yang telah berhasil, (d) adanya program siaran pedesaan melalui radio dan televisi, (e) buku pinter tentang pengelolaan budidaya ikan mas, adanya demplot (proyek percontohan) budidaya ikan mas oleh Loka Budidaya Ikan Air Tawar di Desa Tatelu. Dalam implementasinya sumber dan media belajar masuk dalam wilayah sistem komunikasi. Temuan ini didukung oleh pandangan Sutaryat Trisnamansyah dalam (Wullur,2011:11), yang membedakan dua sistem komunikasi yaitu: "pertama sistem lisan dan kedua sistem media. Dalam sistem lisan komunikasi dilakukan secara langsung antara satu orang dengan orang lain, sedangkan dalam sistem media komunikasi dilakukan melalui mediamedia tertentu seperti surat kabar, majalah, radio, dan televisi”.

Implikasi dalam penelitian ini bahwa komunikasi dengan sistem lisan ini digunakan oleh petani terhadap petugas penyuluh lapangan, petugas loka budidaya ikan air tawar, petani yang telah memperoleh penyuluhan dan pelatihan, serta sesama petani yang berpengalaman dan berhasil untuk memperoleh pengetahuan dan keterampilan tentang pengelolaan budadaya ikan mas.

iv. Proses belajar mandiri petani
dalam meningkatkan usaha
budidaya ikan mas

Temuan hasil penelitian tentang proses blajar mandiri petani ini meliputi aspek kesiapan belajar, implementasi hasil interaksi belajar, dan evaluasi hasil belajar.

1) Kesiapan belajar.

Pada umumnya petani sebelum melakukan interaksi belajar mandiri telah mempersiapkan diri untuk belajar. Kesiapan belajar ini diwujudkan melalui identifikasi kebutuhan belajar yaitu menetapkan usaha budidaya ikan mas sebagai kebutuhan belajar utama di antara kebutuhan belajar lainnya. Dilanjutkan dengan menetapkan materi belajar sesuai dengan tahapan dan kesiapan usaha pengelolaan budidaya ikan mas mulai dari: pemilihan calon induk, perkawinan, pemijahan, pendederan tahap I dan II, pembesaran, panen, pemasaran dan pengelolaan pasca panen, serta pengembangan usaha. Temuan lapangan ternyata tidak semua petani mempelajari keseluruhan proses pembudidayaan ikan mas melainkan mereka hanya mempersiapkan untuk belajar sesuai dengan kebutuhan dan kemampuan yang 
mereka inginkan. Hal ini didukung oleh Musa Alam, (1984) yang mengemukakan: "Seseorang akan siap mempelajari sesuatu apabila ia merasakan perlunya melakukan hal tersebut, karena dengan mempelajari sesuatu itu ia dapat memecahkan masalahnya atau dapat menyelesaikan tugas pekerjaannya setiap hari”. Dengan demikian program belajar didasarkan pada kesiapan belajar melalui analisis kebutuhan secara selektif sehingga petani menyatakan siap dalam dirinya untuk melakukan kegiatan belajar. Hasil penelitian ditemukan bahwa kesiapan belajar informan "BK" lebih tertarik mempelajari usaha budidaya ikan mas mulai dari pembenihan sampai pada pemeliharaan ikan mas komsumsi. Sedangkan kesiapan belajar informan "ML" lebih tertarik untuk mempelajari pemeliharaan benih ikan mas ukuran 3-5 $\mathrm{cm}$ menjadi ukuran 12-15 cm untuk benih ukuran pembesaran budiaya ikan mas melalui kolam air deras. Sedangkan kesiapan belajar informan $(\mathrm{Gg})$ lebih tertarik untuk belajar menekuni proses perkawinan, pemijahan larva hingga menghasilkan benih ukuran 3-5 cm untuk siap produksi benih dalam waktu 2 bulan.

2) Interaksi belajar. Pada umumnya petani melakukan interaksi belajar dengan sumber dan media belajar tanpa direncanakan bersama sebelumnya. Interaksi belajar ini terjadi ketika petani sebagai warga belajar menghubungi sumber belajar yang memiliki pengetahuan dan keterampilan berkenaan dengan kebutuhan belajar petani. Dengan demikian interaksi belajar ini terjadi atas prakarsa atau inisiatif dari petani dengan pendekatan komunikasi interpersonal tanpa ada paksaan dari pihak luar. Proses interaksi belajar ini berlangsung sesuai dengan kondisi sumber belajar tanpa mengganggu tugas atau pekerjaan yang sedang dilakukan oleh sumber belajar dalam bentuk diskusi sambil mengamati sumber belajar melakukan pekerjaan yang berkaitan dengan materi belajar, serta dapat pula melalui proses pengamatan aktivitas pengelolaan budidaya ikan mas tanpa diskusi untuk pengayaan materi pelajaran yang diperoleh. Dari hasil temuan diperoleh bahwa keempat informan melakukan interaksi belajar sesuai kebutuhan belajar yang mereka tetapkan.

3) Implementasi hasil interaksi belajar. Implementasi hasil belajar diperoleh temuan bahwa informan "BK" mengimplementasikan hasil interaksi belajar mulai dari pemilihan calon induk, perkawinan, pemijahan, pendederan tahan I, II, dan III, sampai pada pemeliharaan ikan mas komsumsi. Sedangkan informan "ML" mengimplementasikan hasil interaksi belajar dalam hal pendederan tahap I, II, dan III dimana "ML" membeli larva untuk didederkan. Kemudian informan "Gg" mengimplementasikan hasil interaksi belajar mulai dari pemijahanlarva, pendederan tahap I, II, dan III. Dan informan "FM" mengimplementasikan hasil interaksi 
belajar khusus pemeliharaan benih ikan mas ukuran 12-15 cm untuk pembesaran menjadi ikan mas komsumsi melalui pemeliharaan pada kolam air deras dan petakan karamba.

Hasil belajar mandiri Petani dalam meningkatkan usaha budidaya ikan mas

Dari hasil analisis data diperoleh temuan bahwa hasil belajar mandiri petani dalam meningkatkan usaha budidaya ikan mas, meliputi: (1) peningkatan pengetahuan, sikap dan keterampilan, serta aspirasi petani; (2) peningkatan pendapatan ekonomi keluarga, dan (3) peningkatan status sosial petani dalam masyarakat.

Pertama, peningkatan perubahan pengetahuan, sikap, keterampilan serta aspirasi petani dimaksud ialah terjadinya perubahan perilaku petani setelah memperoleh konsep-konsep baru tentang pengelolaan budidaya ikan mas melalui interaksi belajar dengan sumber dan media belajar yang ada.

Kedua, peningkatan pendapatan ekonomi keluarga yang dimaksud ditandai dengan meningkatnya investasi dan pengembangan usaha budidaya ikan mas, bertambahnya kepemilikan harta material keluarga sebagai hasil usaha budidaya ian mas. Dengan demikian dapat dipastikan pemenuhan kebutuhan material untuk sandang, pangan, papa, kesehatan dan pendidikan bagi anak-anak dapat terpenuhi.

Ketiga, peningkatan status sosial petani dalam masyarakat yang dimaksud ialah terjadinya perubahan status sosial petani yang sebelumnya sebagai anggota masyarakat dengan latar belakang pekerjaan yang berbeda menjadi petani pengelola usaha budidaya ikan mas yang profesional. Karenanya, mereka sering menjadi sumber belajar bahkan menjadi panutan oleh petani lainnya yang masih mengelola budidaya ikan mas secara tradisional.

\section{Implikasi}

- Kesadaran yang terinternalisasi bagi masyarakat petani untuk menjadikan belajar tentang pengelolaan usaha budidaya ikan mas sesuai dengan perkembangan Ipteks sebagai kebutuhan, merupakan prasyarat mutlak kemandirian petani untuk meningkatkan usahanya. Hal ini perlu ditopang dengan upaya penciptaan kondisi belajar mandiri melalui berbagai program kegiatan pendidikan luar sekolah oleh semua instansi yang terkait. Khususnya pelaksanaan program pendidikan luar sekolah oleh Dinas perikanan dan kelautan seperti rekruitmen, seleksi dan penempatan petugas PPL, pengadaan brosur dan buku pinter tentang usaha budidaya ikan mas, serta proyek percontohan atau demplot tentang pengembangan usaha budidaya ikan mas merupakan

- pendekatan strategis yang memungkinkan petani melakukan interaksi belajar. Dengan demikian konsep belajar pendidikan luar sekolah yang menggunakan pendekatan conscientizacao (Poulo Freire, 1972), learning webs (Ivan Illich (2008), learning society and teaching society, serta discovery problem (Lyra Srinivasan, 1977) yang semuanya dalam cakupan pendekatan empowering process (Kindervatter,1979) dapat dikatakan handal bagi masyarakat 
petani untuk melakukan kegiatan belajar mandiri.

- Petani yang dapat dikatakan mandiri harus memiliki etos kerja yang handal dan mapan. Artinya, orientasi nilai budaya yang inovatif produktif terhadap pekerjaan khususnya dalam hal pengelolaan budidaya ikan mas oleh petani harus diwujudkan melalui kecintaan terhadap pekerjaan, kesungguhan, ketekunan dan kreativitas serta keberanian mengambil keputusan. Nilai-nilai budaya masyarakat Minahasa seperti kebersamaan, keterbukaan, tolong menolong, budaya gengsi untuk berprestasi seoptimal mungkin secara kompetitif yang berakar dari"mapalus yang endegeneous" harus ditempatkan pada pencapaian tujuan yang luhur untuk kemajuan bersama. Sedangkan budaya komsumtif, malas, enggan bekerja karena gensi, serta kompetitif yang curang, harus ditekan dan dihilangkan sebagai syarat mutlak melepaskan diri dari keterbelakangan yang bermuara pada kemelaratan budaya, kesejahteraan dan kemiskinan. Kemiskinan menurut Suharto (2009:133) merupkan “ sebuah kondisi yang berada di bawah garis standar kebutuhan minimum, baik untuk makanan dan non makanan, yang disebut garis kemiskinan (poverty line)atau batas kemiskinan (poverty threshold)... “. Karenanya petani harus pekah dan terus menciptakan kondisi sebagai peluang positif yang harus diantisipasi dan dimanfaatkan. Dengan demikian "akan tercipta kondisi self propelling demand yang menghargai dan memanfaatkan transformasi pendidikan sebagai kebutuhan hakiki yang dirasakan" (Adikusumo, dalam Pinontoan, 2009:67).

\section{Rekomendasi}

1. Kepada pihak petani pengelola usaha budidaya ikan mas

a. Seyogianya tidak hanya membatasi untuk mempelajari salah satu sub paket unit usaha budidaya ikan mas, melainkan harus mempelajari dan menguasai teknik seleksi caln induk, pemijahan dan pembesaran usaha budidaya ikan mas.

b. Perlu kiranya mempelajari manajemen usaha khususnya tentangperhitungan biaya modal berupa uang, waktu dan tenaga, serta sumber dana, teknik pemasaran hasil, pemanfaatan hasil, dan pengembangan usaha. Cara ini dapat ditempuh antara lain melalui diskusi, pengamatan perkembangan harga pasar, maupun mempelajari buku tentang teknik-teknik kewirausahaan.

2. Kepada pihak pemerintah desa Tatelu

a. Perlu kiranya mengupayakan pengadaan buku pinter tentang teknik-teknik pengelolaan budidaya ikan mas bekerja sama dengan dinas perikanan dan kelautan dan fakultas perikanan Universitas Sam Ratulangi Manado.

b. Perlu kiranya memanfaatkan petani yang telah berhasil untuk dijadikan sumber belajar bagi petani yang masih mengelola usaha budidaya ikan mas secara tradisional, dengan cara memberikan layanan bimbingan tentang 
teknik pembenihan, pendederan dan pembesaran ikan mas komsumsi.

3. Kepada pihak Dinas Perikanan dan Kelautan Kabupaten Minahasa Utara

a. Seyogianya membentuk sentra-sentra pengembangan budidaya ikan mas sebagai "demplot" atau proyek percontohan di desa-desa sekitarnya untuk lebih merangsang petani pengelola budidaya ikan mas sesuai teknologi baru.

b. Perlu kiranya kerjasama dengan Pemerintah Propinsi dan pihak swasta untuk memproduksi pakan ikan mas jenis "pelet" agar stok pakan dan harga tidak tergantung dari luar daerah. Dengan demikian para petani dapat memperoleh jenis pakan ikan pelet dengan harga yang lebih murah dan mudah diperoleh. Di pihak lain hasil pertanian seperti jagung, singkong, labu, dan kedelai dapat dibeli dengan harga yang layak.

4. Kepada pihak perancang program Siaran Pedesaan melalui radio dan televisi

a. Jadwal penayangan paket diaran pedesaan khususnya tentang pengelolaan budidaya ikan mas hendaknya diinformasikan terlebih dahulu agar petani memiliki kesiapan belajar untuk mengikuti program tersebut sesuai waktu yang ditetapkan.

b. Materi siaran seyogianya bersifat praktis dan mudah dipahami agar petani dapat mempraktekannya di lokasi pekerjaan.

\section{DAFTAR PUSTAKA}

Bogdan, R.C. \& Biklen S.N. (1992). Qualitative Research for Education an Introduction to Theory and Methods. Boston: allyn and Bacon.

Botkin, J. W, et all, (1984), No Limits to Learning: Bridging the Humman Gap. New York: Pergamon Press.

Brookfield, Stephen, (1983), Adult Learner: Adult Education and the Community, SA: Teacher College Press

Freire Paulo, (1985), Pendidikan Kaum Tertindas: Diterjemahkan Tim Redaksi Asosiasi Pemandu Latihan, LP3ES Jakarta.

Illich, Ivan, (2008), Bebaskan Masyarakat Belenggu Sekolah, Terjemahan: A. Sonny Keraf, Yayasan Obor Indonesia, Jakarta.

Kindervatter Suzanne, (1979). Non Formal Education: As An Empowering Process. America: Printes in the Unites States of America.

Knowles. Malcolm S. (1987). The Modern Practice: Andragogy vs Pedagogy. New York: Assosiation Press.

Koentjaraningrat, (1980). Kebudayaan, Mentalitet dan Pembangunan. Jakarta. Gramedia.

Mappa Syamsu dan Anisa Basleman (1994). Teori Belajar Orang Dewasa, Dirjen Dikti, Depdikbud, Jakarta.

Musa Alam, (2004), Teknik-Teknik Budidaya Ikan Mas (Cyprinus Carpio.L), Gramedia Jakarta.

Nawawi Ismail, (2006). Pembangunan dan Problematika Masyarakat: Kajian Konsep, Model, Teori dari Aspek Ekonomi dan Sosiologi. CV. Putra Media Nusantara. Surabaya.

Pinontoan Marien, (2010) Pelaksanaan sistem Pembelajaran Berwawasan Kewirausahaan, Cahaya Abadi Tulungagung.

Rogers, Everett M. (1983) Diffusion of Innovations, Third Edition. New York: Adivision of McMillan Publishing Co. Inc. The Free Press.

Srinivasan Lyra (1977). Perspectives on NonFormal Adult Learning Word Education. New York: The Free Press. 
Sudjana, H. D. (2001), Pendidikan Luar Sekolah: Wawasan, Sejarah Perkembangan, Falsafah, Teori Pendukung, Asas, Falah Production, Bandung.

Sudjana, H. D. (2006), Evaluasi Program Pendidikan Luar Sekolah: Untuk Pendidikan Nonformal dan Pengembangan Sumber Daya Manusia, PT Remaja Rosdakarya, Bandung.

Suharto Edi, (2009). Membangun Masyarakat Memberdayakan Rakyat: Kajian Strategis Pembangunan Kesejahteraan Sosial \& Pekerjaan Sosial, Rafika Aditama. Bandung
Sumaatmadja Nursid, (2003), Manusia dalam konteks Sosial, Budaya, dan Lingkungan Hidup, Bandung Alumni.

Supriyanto, (2008). Pendidikan Orang Dewasa; Dari Teori hingga Aplikasi, Bumi Aksara Jakarta.

Wullur Mozes M. (2010). Perencanaan Pendidikan Luar Sekolah, Cahaya Abadi Tulungagung

Wullur Mozes M. (2011). Analisis Sistem Pendidikan Luar Sekolah, Cahaya Abadi Tulungagung. 